911.2:551.4

\author{
. \\ ьвівський н ціон льний університет імені в н \\ вул. . орошенк , 41, м. ввів, 79000, кр їн
}

орушено дискусію про специфічне явище л ндш фтного устрою природи $\quad$ рп т, виявлене й озн чене . іллером як стрі льний рівень орг ніз ції гірського л ндш фту. пропонов но розгляд ти стрі льність у числі універс льних з кономірностей еволюції просторово-ч сової структури гірського л ндш фту.

лючові слов : стрія, стрі льність, рп ти, озточчя.

хему розвитку н уки ч сто зобр ж ють у вигляді стилізов ного дерев : доцентров коренев систем н укових джерел - центр льний концепту льний стрижень відцентрове розг луження зре лізов них т перспективних н укових н прямів. подібних схем х добре простежуються вузли ключових н укових проблем, зверт тися до яких корисно н кожному ет пі розвитку н уки нез лежно від того, н скільки д лекими вони вид ються з позицій новітнього н укового прогресу т нових проблем, які вирішують сьогодні. ке зверт ння з вжди є своєч сним, оскільки з безпечує нерозривний зв'язок суч сного н укового пошуку з фунд мент льними положеннями і д $€$ Змогу б чити їх у новому світлі.

тр диційному л ндш фтозн встві, як і в новітній л ндш фтній екології, до т ких проблем передусім н лежить учення про морфологічну структуру геогр фічного л ндш фту (геосистеми), коріння якого сяг є н йглибших пл стів вікової історії н укової г лузі. о середини ст. воно сформув лось у концепцію ієр рхічної системи л ндш фту, ступені бо рівні орг ніз ції якої, визн чені м йже одноч сно і нез лежно в різних н укових школ х різних кр їн, як виявилося, можн узгодити між собою у принципових позиціях сумірності. я обст вин д л поштовх до дослідження інших способів структурного впорядкув ння л ндш фтної системи і спроб розгляду їі як поліструктурного об'єкт .

г д ні н пр цюв ння трив лий ч с стосув лися, головно, рівнинних л ндш фтів. 60-х рок х . іллер з пропонув в одну з піонерних розробок морфологічної структури гірського л ндш фту н прикл ді м сиву орногори, яку згодом з стосув в для інших р йонів кр їнських рп т. я схем відрізняється більшою скл дністю ієр pхічного устрою з вдяки двом оригін льним одиницям - літогенетичній стрії т ороклім тичному сектору.

бгрунтув ння літогенетичної стрії ст ло помітною подією у молодому гірському л ндш фтозн встві й зумовило жв ве з цік влення дослідників. дискусіях т польових робот х поступово утвердил ся центр льн позиція нової одиниці у структурі гірського л ндш фту, як з повнил зн чну морфологічну прог лину між його мікро-

(C) едірко ., 2012 
т м крорівнями т в комплексно-природничому вир женні відобр ж є ключові геоструктурні й петрогр фічні особливості східного відтинку рп тської дуги.

ьогодні в жко однозн чно н зв ти обст вину, як перев ж л у зн ходженні специфічного рівня орг ніз ції гірських л ндш фтів. ожемо тільки конст тув ти, що “зн хідк леж л"н перехресті трьох шляхів.

1. оскон ле володіння регіон льною природничою інформ цією індик ційного х p ктеру. труктурно-петрогр фічн зумовленість рельєфу т його вплив н розподіл гідроклім тичних пок зників у гор х відомі зд вн . етермінув льний вплив фізикохімічних особливостей літологічного субстр ту н $\mathrm{x}$ р ктер лісорослинного покриву т кож ст в предметом досліджень ще н поч тку ст. (прин ймні, почин ючи з кл сичних пр ць. орозов т . исоцького). ктично озн чений фізико-геогр фічний ефект, "розщеплений" н п ри елемент рних визн ч льних впливів, до поч тку 60-х років уже не був одкровенням. изрів ч с д ти цьому ефекту об'єктивне комплексне тлум чення, і це було зроблено у вигляді виділення особливого (стрі льного) рівня гірського л ндш фту.

о того ч су м йбутній втор термін уже твердо стояв н теоретичних позиціях визн ч льної ролі літогенного чинник в утворенні л ндш фтно-морфологічних одиниць, сформульов них . олнцевим. бгрунтув ння стрії як “комплексу літологічно однорідних урочищ” ст ло под льшим розвитком цих позицій.

з с д х зг д них теоретичних перекон нь т регіон льних 3 кономірностей, стрію ще треб було вміти виділити у моз їчній структурі гірського л ндш фту, для цього потрібно було м ти не бияку спостережливість, неордин рне б чення і розуміння устрою природи.

к би т м не було, стрію зн йдено і визн чено. твердження нової л ндш фтної одиниці відбув лося, м буть, єдино пр вильним шляхом - у процесі польового к ртув ння. йліпше стрі льні з кономірності вивчені для флішової ч стини кр їнських

рп т. першому н ближенні з фіксов ний своєрідний стрі льний ефект у л ндш фт х височин, зокрем , н озточчі, де н поч тку 90-х років опис ний зв'язок низки лісових субформ цій зі структурно-літологічними рівнями. тже, 330 років стрія поступово перейшл зі сфери дискусії у сферу пр ктики польових л ндш фтних досліджень.

дн к, досвід к ртув ння виявив низку проблем в однозн чному тлум ченні цього специфічного явищ устрою природи. од льше ігнорув ння суперечностей у н йближчому ч сі може ст ти г льмом як теоретично-методичного, т к і прикл дного розділів гірського л ндш фтозн вств . ожемо з свідчити, що вн слідок першої спроби уз г льнити л ндш фтну вивченість кр їнських рп т н к рті м сшт бу 1:500 000 втор стрії н голошув в н потребі под льшого пошуку і не виключ в можливості перегляду деяких положень.

копичені проблеми згрупов но у три блоки:

- ті, що стосуються місця стрії у морфологічній структурі л ндш фту;

- ті, що стосуються “літологічної однорідності” основи л ндш фту;

- ті, що стосуються зовнішнього (лісорослинного) прояву глибоких структурнопетрогр фічних з кономірностей.

оротко розглянемо їх у т кому порядку.

1. ослідники л ндш фтного устрою рп т різних поколінь ч сто спинялися перед досить суперечливим ф ктом: стрія не тільки об'єднує літологічно однорідні урочищ в одну систему вищого р нгу, й роз'єднує об'єктивні природні єдності спіль- 
ного морфогенезу нижчого р нгу. це стосується не тільки урочищ, й “неподільних" ф цій. іч у тому, що флішові відкл ди, як літогенн основ л ндш фтно-морфологічних одиниць, х р ктерні ритмічною ш рув тістю. рібноритмічні літологічні відмінності обчислюють метр ми і н віть дециметр ми, що зумовлює потребу розчленовув ти елемент рні одиниці. оден з випробув них способів подол ти цю суперечність досі не д в позитивного результ ту - ні спроби ввести дод ткові рівні орг ніз ції у скл дну ієр рхічну систему гірського л ндш фту, ні спроби вз ємного переміщення с мих рівнів у системі. роблем є відкритою.

2. кт “літологічної однорідності” т кож виявився дуже і дуже неоднозн чним.

рив лий ч с повторюють типову помилку мех ністичного тлум чення геологічного фунд менту л ндш фтної стрії. ежі геологічних світ і л ндш фтних стрій не можуть збіг тися з тої простої причини, що з основу їхнього виділення взято різні принципи. першому вип дку вчені відд ють перев гу стр тигр фічним критеріям, у другому - фізико-хімічним вл стивостям гірських порід, які визн ч ють х р ктер екзогенних процесів, скл д біогенної н дбудови тощо. ерідко, отже, у р мк х однієї геологічної світи м ємо спр ву з двом -трьом , то й більшою кількістю спр вді однорідних літологічно смуг, які цік влять н с з погляду комплексного фізико-геогр фічного ефекту. йліпше, м буть, це можн проілюструв ти прикл дом стрийської світи, як об'єднує контр стні з фізико-хімічними пок зник ми геологічні відкл ди.

ітологічно однорідні смуги пронизують кр їнські рп ти від кр ю до кр ю, зв'язуючи л ндш фти не тільки одного, й різних видів. ідкл ди цієї ж стрийської світи, н прикл д, виходять н денну поверхню пр ктично безперервною пон д 250-кілометровою смугою в окутсько- уковинських рп т х, орг н х, колівських т ерхньодністерських ескид х. ідомі вип дки розходження і сходження цих смуг, причому різні їхні ч стини опиняються у різко відмінних умов х циркуляційного, інсоляційного т гідрологічного режимів (один із прикл дів-полонин

перелічених т інших прикл д х стрія є явищем інтерл ндш фтним, вл стивим усій гірській споруді н зр зок висотної поясності чи ярусності.

уттєво порушують строгу стрі льну послідовність четвертинні відкл ди. лювільні, гляці льні, флювіогляці льні відкл ди в гірських долин х перебир ють н себе роль літогенної основи. одібне явище спостеріг ють у високогір'ях, де курумники (греготи) обширними потужними пл щ ми перекрив ють корінні породи і глибоко вторг ються у середньогір'я. підніжжях схилів н копичуються і злив ються конуси осипів - шлейфи, поступово з войовуючи щор з вищі гіпсометричні позиції. середніх ч стин х схилів т кож д леко не з вжди можн сміливо укл д ти стрі льні контури 3 корінними літологічними озн к ми: є місця, де ч стот ізогіпс н топок рті іде льно відобр ж є зміну порід, між ними ч сто доводиться проводити межу пр ктично н впом цки (тут би треб , з пропозицією того ж . олнцев , користув тися штриховими лініями). д леко не в кожному вип дку ситу цію можн пояснити недоскон лістю топогр фічних к рт. ідбув ється безперервне делюві льне переміщення м терілу, нівелюв ння профілю т стрімкості схилу, інші гр вігенні процеси. ерелічені зміни субстр ту не мин ють безслідно в біогенній н дбудові л ндш фту. подібних вип дК х іде льні стрі льні з кономірності суттєво ускл днюються. ктично м ємо спр ву тільки з м ркув льними фр гмент ми корінних стрі льних утворень, між ними - явищ іншого порядку.

ведені прикл ди переконують, що і цей проблемний блок є відкритим. 
3. йв жчим з вд нням польових досліджень у р зі скл д ння л ндш фтної к рти $€$ зн ходження декв тного генетико-еволюційного відобр ження літогенного фунд менту в біогенній н дбудові. етодичні рекоменд ції у цьому пит нні зводяться до того, що л ндш фтній стрії н йповніше відповід є лісорослинн субформ ція. спр вді, в меж х однієї стрії спостеріг ємо м ло не весь лісорослинний спектр регіону, вир жений полярними ед фотоп ми: від ініці льних березово-соснових борів до клім ксних ялицево-букових грудів. віть н суглинисто-в лунних моренних п см х, під якими глибоко похов ні корінні відкл ди, н тлі домінув ння чистих смерекових суборів тр пляються то кленово-букові, то соснові угрупов ння.

одібно до того, як проблемно вловити стрі льні переходи н вирівняних схил х, ще скл дніше зн ходити їх у монотонних смерекових ліс х. ерідко ці лісові м сиви розчленовують (“ріжуть по живому”) н підст ві сл внозвісної к рп тської "смереком ніï", хоч д леко не в усіх вип дк х нею можн пояснюв ти високу монокультурність. лоб льні клім тичні зміни стимулюють безперервний сукцесійний процес: зміш ні ліси то піднім ються у високогір'я, то відступ ють у передгір'я, поступ ючись місцем суб льпійському криволіссю. ьогоднішню високу смерекову монокультурність к рп тських лісів, очевидно, треб пояснюв ти не тільки лісогоспод рськими тенденціями ост ннього сторіччя, й інерційними н слідковими явищ ми в рослинному покриві від ост ннього похолод ння в льпійській вропі.

тже, у лісорослинному покриві т кож виявляється фр гмент рний х р ктер стрі льних 3 кономірностей. уже рельєфним він $є$ в ініці льній т близькій до неї ст діях сукцесії. і ст дії іноді з тягуються н століття через інтенсивність гр вігенних процесів і постійне оголення субстр ту. н ближенням до клім ксної ст дії зрост є унез лежнення біогенної н дбудови від субстр ту. р ктично клім ксн ст дія - це якісно нов природн систем, озн к еволюції. віть після розп ду (деструкції) клім ксної системи ініці льн ст дія уже буде зовсім іншою, нез лежною від корінного субстр ту.

ерелік відкритих проблем можн продовжити. огляду н суч сний ст н вивчення порушеного пит ння можн з пропонув ти т ке:

стрі льність - н дзвич йно в жлив, м ло вивчен природн 3 кономірність л ндш фтної диференці ції гір, як , швидше $з$ все, не н лежить до розряду кл сичної морфологічної структури л ндш фту;

- $\quad$ ефект стрі льності - це ч совий зріз еволюції гірського л ндш фту, фіксов ний конкретною ст дією сукцесії лісорослинного покриву н тлі урізном нітнення літологічного субстр ту т клім тичних флукт цій.

m ття: н дійшл до редколегї 25.09.2011 прийнят до друку 20.12.2011 


\section{STRIAL LEVEL OF MOUNTAIN LANDSCAPE STRUCTURE OR THE EFFECT OF STRIALITY IN THE LANDSCAPE STRUCTURE OF MOUNTAINS?}

\section{O. Fedirko}

Ivan Franko National University of Lviv, . Doroshenko St., 41, UA - 79000 Lviv, Ukraine

A discussion has been raised concerning the specific phenomenon of landscape structure of Carpathian mountains, which G. P. Miller has defined as a strial level of the structural arrangement of a mountainous landscape. It is suggested to consider the notion of striality within the universal evolution of spatial and temporal structure of a mountainous landscape.

Key words: stria, striality, Carpathians, Roztochya.

\section{- едирко}

ьвовский н иион льный университет имени в н

ул. . орошенко, 41, г. ввов, 79000, кр ин

однято дискуссию о специфическом явлении л ндш фтной структуры рп т, определенном . иллером к к стри льный уровень орг низ ции горного л ндш фт . редложено р ссм трив ть стри льность в числе универс льных з кономерностей эволюции простр нственновременной структуры горного л ндш фт .

лючевые слов : стрия, стри льность, рп ты, сточье. 